\title{
ENTREPRENEURIAL ORIENTATION IN THE SEGMENT OF MICRO-ENTERPRISES: EVIDENCE FROM CZECH REPUBLIC
}

\author{
Mehmet CIVELEK ${ }^{3}$, Ashiqur RAHMAN ${ }^{4}$ Ludmila KOZUBIKOVA ${ }^{5}$
}

\begin{abstract}
The objective of this comprehensive research is to identify and explore the dissimilarities of gender and education level of entrepreneurs and enterprises' age with regards to entrepreneurial orientation (EO) in the segment of micro enterprises. All of the dimensions of EO are included such as innovativeness, risk taking, proactiveness, competitive aggressiveness and autonomy for our analysis. The data that we have used for this study, was collected by a structured questionnaire during 2015 in Czech Republic, and consists of 1141 small and medium-sized enterprises (SMEs) and 740 of them are defined as micro enterprises by using the definition of European Commission. The empirical results of our study indicates a that university educated micro-entrepreneurs are more innovative and autonomous comparing with lower educated micro-entrepreneurs and also younger micro firms are more innovative, risk taker and proactive than the older micro firms. However, our results do not show any significant differences between men and women in relation to the all components of EO. Our result can be explained by having higher percentage of university educated women micro entrepreneurs comparing with their men counterparts and education may have a substitution effect on the gender based differences in the segment of micro firms.
\end{abstract}

\section{KEYWORDS}

Entrepreneurial Orientation, Micro Enterprises, Gender, Education, Firm Age, Czech Republic

$J E L$

L26, M21

\section{INTRODUCTION}

It is widely acceptable that SMEs have significant impacts on the economic development for both developing and developed countries. According to Islam et al. (2011), SMEs have flexible structures, can be easily adaptable to the changing market conditions such as demand and supply situations, and also they encourage improving entrepreneurial competencies and private ownership,

\footnotetext{
${ }^{3}$ Mehmet Civelek, Department of Enterprise Economics, Faculty of Management and Economics, Tomas Bata University in Zlin, Mostni 5139,76001,Zlin. Email: civelek@fame.utb.cz

${ }^{4}$ Ashiqur Rahman, Department of Enterprise Economics, Faculty of Management and Economics, Tomas Bata University in Zlin, Mostni 5139, 76001, Zlin. Email: rahman@fame.utb.cz

${ }^{5}$ Ludmila Kozuikova, Department of Enterprise Economics, Faculty of Management and Economics, Tomas Bata University in Zlin, Mostni 5139, 76001, Zlin. Email: kozubikova@fame.utb.cz
} 
create employment, operate in variety of economic activities, and play active roles in exports and trades. For instance, Karel et al. (2013) state that SME sector made contribution to $51.5 \%$ (around 1478 billion CZK) of total export and also contributed to $56.6 \%$ (about 1515 billion CZK) of total import in 2011 in the Czech Republic. Moreover, SMEs have some certain characteristics such as having limited size, a lower level of diversification, low capital strength, more limited market and a higher risk. (Aleksandr et al., 2016)

On the other hand, Thapa (2015) makes an explanation that even though micro firms have different properties from other kinds of businesses, they are usually classified under small-sized enterprises. Liedholm (1990) provides a definition that micro enterprises have nine or lower number of employees. On top of that, Brugger and Rajapatirana (1995) found that around 150000 people start to work in a job in developing countries and majority of them will be worked for micro enterprises such as owners or workers. On the other side their income levels are lower comparing with other size of enterprises. For example, Thapa (2015) clarifies that micro enterprises' total assets differ up to $\$ 10000$ and total annual sales are varied until $\$ 100000$. Additionally, the Commission of European Communities (2003) states that total annual turnover and/or total annual balance sheet of micro enterprises are fewer than EUR 2 million.

According to Covin and Wales (2012), even if age, size and ownership of organisations are different, studies of entrepreneurial orientation aim to orientate to organisations in entrepreneurial activities. For this reason, micro enterprises and their EO is a vital subject for entrepreneurship literature. Defined by Jelenc et al. (2015), EO is a tradition that evaluates how firms are prone to entrepreneurial attitudes. In the previous studies, there are various measurements which are used to evaluate EO. However, there are two types which are applied by majority of researchers. The first one is Miller's (1983) which considers three components of EO, namely, proactiveness, innovativeness and risk taking. Another one is provided by Lumpkin and Dess (1996), takes five dimensions of EO into account by adding autonomy and competitive aggressiveness with Miller (1983) conceptualization.

Another issue is that founder's human capital is not only a true determinant of firm survival but also it detects the performance of a firm (Cressy, 1996). Education and experience are critical components of human capital so these factors can also affect the performance. Moreover, Berrone et al. (2014) emphasize that previous experience and education are some individual characteristics which determine the performance of micro enterprises. Additionally, they describe the importance of gender which is also one of determinants of the performance for micro enterprises. According to Arenius and Minniti (2005), demographic variables such as age, sex and education are important to explain the trend in entrepreneurship process. Furthermore, Belas et al. (2015) state that there are some entrepreneur's characteristics that have significant impacts on business success, such as gender, level of education, age, managerial skills, and experience, in addition to physical and emotional family support.

When examining the dissimilarities of these demographic variables and entrepreneurs' and enterprises characteristics such as gender, education level of entrepreneurs and age of companies on the EO, a large number of studies are in existence in the literature and they all indicate various results. Considering the role of gender, some previous research found significant differences between males and females on EO (Runyan et al., 2006; Lim and Envick, 2011; Jelenc et al., 2015; Ayub et al., 2013; Goktan and Gupta, 2015). However, Diaz-Garcia and Jimenez-Moreno (2010) find that there is a lack of differences between males and females in entrepreneurial intention.

In terms of education, Jelenc et al. (2015) find that education abroad have effects on individual entrepreneurial orientation and also Altinay and Wang (2011) prove that entrepreneurs who have higher education levels can make positive contributions to their enterprises' EO. Furthermore, 
Arenius and Minniti (2005) find that secondary or higher education is a significant factor for explaining the entrepreneurship process. According to Rauch and Rijsdijk (2013), people who have higher education level can effect to business growth positively. On the other hand, Thapa (2015) and Jelenc et al. (2015) did not find any positive relationship between education and performance. With regards to the firm age, younger and older enterprises have some differences on their EO due to resource accumulation (Anderson and Eshima, 2013). Moreover, Islam et al. (2011) analysed the success of firm with regards to the age of companies and they have found some significant differences between older and younger firms. Altinay and Wang (2011) clarify that if an owner of an enterprise has more experience, he can influence to his firm's EO positively. In contrast, Berrone et al. (2014) found that work experience as self-employed have no significant effect on firm performance.

The aim of this paper is to find out the differences in gender and education level of entrepreneurs and age of enterprises with respect to various dimensions of EO such as innovativeness, risk taking, proactiveness, competitive aggressiveness and autonomy in the segment of micro enterprises. In this present study, we include three varied features of an entrepreneur and enterprises, such as gender and education level of an entrepreneur, and age of firms to examine their differences on the five dimensions of EO. Although many studies about EO mainly focus on the three components of EO which are innovativeness, risk-taking and proactiveness (Runyan et al., 2006; Moreno and Casillas, 2008; Roxas and Chadee, 2012; Pett and Wolff, 2012), the novelty of the paper is that we incorporate all the components of EO dimensions which are firstly defined by Lumpkin and Dess (1996). As we mentioned above, there are quite a bit number of studies found some significant dissimilarities of gender and EO. However, our results show that there is no significant differences exist between males and females micro entrepreneurs in all the indicators of EO. On the other hand, we found that there are some differences between education levels on innovativeness, competitive aggressiveness and autonomy. We also found some results that micro entrepreneurs who have university degree are more innovative and autonomous than their counterparts who have lower degrees. Although, we achieved a result that there are differences between different education levels on competitive aggressiveness, this finding is not statistically significant. Furthermore, our results indicate that younger micro enterprises are more innovative, risk taker and proactive comparing with older micro enterprises.

Considering the previous studies, this paper is the only study that sheds light in the differences of gender, education level of entrepreneurs and enterprises' age in connection with all dimensions of EO in the segment of micro enterprises. Our research is significantly different from the existing literature in entrepreneurship studies because it introduced some significant characteristics of micro entrepreneurs and microenterprises and five components of EO. Moreover, we focus on microenterprise segment from a broad perspective which has never used before especially in European and the rest of entrepreneurship studies in relation with EO. For these reasons, our study will provide to distinguish the dissimilarities between females and males entrepreneurs, higher and lower educated entrepreneurs and older and younger firms in the matter of EO in the micro segment.

In the second section, we will review the theoretical part of this study about definitions and characteristics and some performance indicators of micro enterprises, explanations of all five dimensions of EO and the information for the impacts of different variables such as age of firm, education level and gender of entrepreneur on EO. Next, we will explain the research methodology and data of this study in third part of the paper. In section four, our results will be presented with discussion. In the last part of our study, we will provide a brief review of our results, some limitations and recommendations of our research. 


\section{LITERATURE REVIEW}

Segment of micro enterprise is one of the considerable factors that affect economic growth and conditions of countries. Although, medium and large scale enterprises are examined by many researchers, topic of micro enterprises came into prominence after the institutionalization of microcredit programmes which are provided by Grameen Bank in Bangladesh around 1970s (Thapa, 2015). After this situation, many academicians have become more concerned about micro enterprises and have provided many studies in this area. According to the Commission of the European Communities (2003), micro enterprises have workers less than 10 people. They have also various income levels which differ country to country. Larson and Shaw (2001) explain that micro firms are mainly family-owned, one-person activities and located in rural areas. Moreover, this kind of firms work in different sectors such as manufacturing, service and sales and their organization structures are generally based on sole proprietorship, partnership or a family firm (Welsh et al., 2013). On top of that, business structure of micro enterprises is not very complicated so they can change their activities and sectors much easier than the bigger size enterprises due to having lower level of obstacles, capital and skills to start up a business. Furthermore, by having flexible business structure, they can have more opportunities than bigger enterprises to respond customer and market demands quickly and additionally, micro firm segment is one of important factors that can decrease the unemployment rates because of presenting new job possibilities. (Welsh et al., 2013)

Mintzberg (1973) defines that "In the entrepreneurial mode, strategy-making is dominated by the active search for new opportunities" as well as "dramatic leaps forward in the face of uncertainty" (p. 45). Moreover Miller (1983) states that "An entrepreneurial firm is one that engages in productmarket innovation, undertakes somewhat risky ventures, and is first to come up with 'proactive' innovations, beating competitors to the punch" (p. 771). On the top of that Lumpkin and Dess (1996) explain that "EO refers to the processes, practices, and decision-making activities that lead to new entry" as characterized by one, or more of the following dimensions: "a propensity to act autonomously, a willingness to innovate and take-risks, and a tendency to be aggressive toward competitors and proactive relative to marketplace opportunities" (pp. 136-137). Also, Covin and Lumpkin (2011) clarify that "EO is a firm-level phenomenon (more precisely, EO is a strategic business unit (SBU) level phenomenon) where the "unit" can range from a non-diversified small to medium-sized enterprise (SME) to a single business unit of a multi business firm".

Considering the dimensions of EO, Covin and Wales (2012) explain that there are two constructs to examine EO. First one is multidimensional (second order) which includes three dimensions, namely innovativeness, risk taking and proactiveness and overlaps with Miller's (1983) definition of EO. Second one is connected with Lumpkin and Dess (1996) description of EO and it contains five components of EO namely, innovativeness, risk taking, proactiveness, competitive aggressiveness and autonomy (first order). Although, there are more studies which have applied for the multidimensional construct in the literature, quite few number of researches which have used first order construct are also exist (Lim, and Envick, 2013; Moss et al., 2015, Lechner and Gudmundsson, 2014; Islam et al., 2011; Ayub et al., 2013).

With regards to factor of gender, by using a data from 389 university students in four countries namely, USA, Fiji, Korea and Malaysia, Lim and Envick (2013) provide that male students show higher results in risk taking, proactiveness, competitive aggressiveness and autonomy than female students. Langowitz and Minniti (2007) argue that, women are less prone to take risk comparing with men and they try to avoid risk more than the men when they play gamble. Similarly, results of some studies indicate that men take more risk than then women and which clarify that women choose lower risky options than men (Sexton and Bowman-Upton, 1990; Powel and Ansic, 1997; Diaz-Garcia and Jimenez-Moreno, 2010; Ayub et al., 2013). Additionally, Wagner (2007) 
emphasizes that fear of failure is an important factor that determines the differences between male and female whether to launch a new business or not.

Furthermore, Ismail (2014) proves that need for autonomy and power and risk taking propensity are the lowest entrepreneurial competencies of women in micro, small and medium scale enterprises. Goktan and Gupta (2015) also state that females perceive the environment more competitive and tough comparing with males so they are less prone to start a business. Similarly, Minniti and Nardone (2007), argue that men are more opportunity seeker than females to start a new business. By using a data from Ireland, O'Gorman and Terjesen (2006) describe that males are more opportunity oriented than the females, and females have lack of previous experience or management skills to start-up a new business and these are the major problems for females' entrepreneurship development in Ireland.

By using a wide range of data from 28 countries, Arenius and Minniti (2005) find that men are more motivated than women to become an entrepreneur. Using a data from 1575 undergraduate business students in Turkey, United States, Hong Kong and India, Goktan and Gupta (2015) find that men have higher levels of individual entrepreneurial orientation than women. By analysing four countries namely, USA, Korea, Malaysia and Fiji, Lim and Envick (2013) emphasize that females are less aggressive in the competitiveness rather than males. Moreover, Ayub et al. (2013) state that women are less innovative and autonomous than their male counter parts. Lim and Envick (2011) give an explanation that when females want to be an entrepreneur, their behaviours such as need to achieve and independence show similarities with their male counterparts. Moreover, Bird (1993) observes that females and males have strong similarities in some characteristics which are related with entrepreneurship such as autonomy, success and control. On top of that Jelenc et al. (2015) find that there is no difference between men and women in the matter of risk taking and innovativeness. According to Runyan et al. (2006) no difference found in the dimension of proactiveness between men and women.

When we take the level of education variable into consideration, Berrone et al. (2014) posit that the level of education is a significant determinant which shapes the framework of a microenterprise. Clercq and Arenius (2006) indicate that individual education level has positive impacts on seizing entrepreneurial opportunities with regard to growing firms. According to Altinay and Wang (2011) analytical, computational and communicational competencies of entrepreneurs are improved by a higher level of education. Moreover, Berrone et al. (2014) state that well educated micro entrepreneurs might have more technical abilities and business intelligence which could influence the performance of the firms and they find that education has positive effect on performance of micro enterprises. These attitudes of educated entrepreneurs can also provide opportunities for firms to be more competitive in their market. Furthermore, Van der Sluis and Van Praag (2008) emphasize that there is a significant relationship between higher level of education and higher performance of the entrepreneurship when sales or profitability are taken into account and this is also possible for sustainability of firms.

On the top of that, Mengistae (2006) find that an entrepreneur with higher levels of education can conduct the business more successfully than an entrepreneur who have less than secondary of primary education. Also, Altinay and Wang (2011) explain that education can improve some characteristics of entrepreneurs, such as creativity, flexibility, self-direction and the skills to cope with different issues and thus, make positive contribution to innovativeness. Mervel and Lumpkin (2007) highlight that education have positive impacts on innovation radicalness. De Winne and Sels (2010) prove that education has significant influences on innovation output. By analysing 389 Japanese firms, Kato et al. (2015) highlighted that education of an entrepreneur positively effects to his investment into the research and development projects so his small firm can be more innovative in the specific market. In their study, Rauch and Rijsdijk (2013) describe that entrepreneurs who are 
highly educated are negatively related with firm failure. By examining a data from 139 owners of Turkish ethnic small enterprises in London, Altinay and Wang (2011) find that education has positive relationship with innovativeness, risk taking and proactiveness of firms. Van der Sluis et al. (2005) clarify that when entrepreneurs are highly educated, they are more prone to be selfindependent than the regular wage earners. Additionally, Ismail (2014) proves that need for autonomy is the only component which differs between the levels of education of Indonesian women and men entrepreneurs. According to Islam et al. (2011), entrepreneurship education enhance the existence of new ventures, tendency of self-employment, improving new products and self-employed graduates owning a high technology firm.

However, by examining 500 university students in Nigeria, Mamman (2014) finds that entrepreneurship education does not have impacts on capacity building for these students to set up their new ventures due to lack of technical entrepreneurship education. Similarly, Oosterbeek et al. (2010) investigate an entrepreneurship education program in Netherland and find that entrepreneurship education does not have any significant impact to create competencies for collage level students to set up their own business. Bartos et al. (2015) find that university educated entrepreneurs are more motivated to start their own business than the school educated entrepreneurs as they find it as a mission to be independent.

To view the last variable, we will look at the age of the firm. According to Luo et al. (2005) and Rosenbusch et al. (2011), there are more probabilities that younger firms show more entrepreneurial strategic behaviours rather than older. Hausman (2005) shows that younger micro firms perform better in innovativeness comparing with older micro firms. Anderson and Eshima (2013) show that having lack of routines and more organic organizational structures young firms can make more radical innovations with having potential for growth and also they can be easily adaptable to changing environments. Anderson and Eshima (2013) find that innovativeness, proactiveness, and risk taking are more positively related to firm growth among younger SMEs than older firms. Hence, due to these attitudes of young firms they can show more competitive behaviours than their older rivals. Moreover, younger firms are not well disciplined and usually careless and more autonomous in strategic decision making process (Eisenhardt, 1989). Similarly, Rosenbusch et al. (2011) state that younger firms are more active to gain better chances from innovativeness, proactiveness and risk taking strategic behaviours than older firms.

According to Berrone et al. (2014), previous experience might enhance the process of decision making and information. Islam et al. (2011) emphasize that firms having longer time in operation are more successful than the short lived firm. On top of that, by using a sample from 1000 SMEs in the UK, Laforet (2013) observes that older companies are better for innovation than the young companies due to having more experienced employees. Thapa (2015) argues that in progress of time, firms get more experiences and make more observation and be informed by these actions. As firms, entrepreneurs also have more experiences, when they carry on their business throughout this learning process. In this regard, some studies highlight that entrepreneurs who have more experiences take more risk, have higher level of innovativeness and proactiveness than the less experienced entrepreneurs (Jelenc et al., 2015; Altinay and Wang, 2011; Kraus, 2013).

Marques et al. (2013) also state that cognitive factors such as high risk exposure, recognition of opportunities and perception of probability to success are related to experience. Additionally, some studies argue that experience of an entrepreneur plays an important role in the economic growth of the firm (Brunow and Hirte, 2006; Mengistae, 2006; Islam, 2011). However, Ismail (2014) finds that experience of women entrepreneurs have no differences in entrepreneurial competencies. On the other hand, Rauch and Rijsdijk (2013) do not find any significant effect of specific work experience with firm growth. Moreover, Levesque and Minniti (2006) make an explanation that when a person gets older and has more experiences she rather wants to have a more stable life with 
a regular income source. According to Levesque, Minniti (2011), older people are less motivated to take any business initiatives at their late age.

\section{DATA AND METHODOLOGY}

The purpose of this paper is to find the EO differences in relation to gender and education level of Czech micro entrepreneurs. On top of that, to show whether entrepreneurial orientation may differ according to the age of the enterprise.

On the basis of the survey of the quality of the business environment, the study was implemented by using a questionnaire in the Czech Republic in 2015. The total number of 1650 firms was chosen randomly from the Albertina database. These companies were contacted by e-mail or telephone to fulfil the questionnaire that is presented on website https:/docs.google.com/forms/d/1U9coaC5JRL0N2QOOO6Xb8j3mnaZXdSM47Kugt4EDGFo/vie wform? usp=send_form. We have received 1141 responses from the SMEs which are located in 14 different regions of Czech Republic. 740 respondents $(65 \%)$ of them are belonged to the segment of micro enterprises which identified by the Commission of European Communities, have employees between 0 and 9 .

In relation to the gender and education, the structure of micro entrepreneurs was as follows: $73 \%$ male (540 respondents), 27\% female (200 respondents); $29 \%$ have graduated from university (215 respondents), $71 \%$ have other types of education level (525 respondents). 37\% of women micro entrepreneurs (74 respondents) have university degree whereas only $25 \%$ of men micro entrepreneurs (108 respondents) are graduated from university.

The structure of the micro enterprises in relation with their age was as follows: $53 \%$ of micro firms operate more than 10 years (390 firms), 29\% of them exist between 1 and 5 years (215 firms) and $18 \%$ of companies are in existence between 5 and 10 years (135 firms). In our study, we assume that companies are exist 10 and more years are older firms and the others which operate less than 10 years are younger firms.

The questionnaire was consisted of 52 questions and nine questions were asked to respondents in connection with their firms' location, sector of their businesses, the duration of their firm, size of their company, their education level, their gender, their motivation factors to set up a new venture, the qualities and skills which an entrepreneur strongly need to have. Other forty three enquiries were asked to the respondents to evaluate the five dimensions of entrepreneurial orientation by using five point Likert scale (1-strongly agree, 2-agree, 3-undecided, 4-disagree, 5-strongly disagree).

Being in line with the chosen aim, five enquiries (one enquiry for each of the dimensions) were selected to explore the results for innovativeness, risk taking, proactiveness, competitive aggressiveness and autonomy of the businesses. In the context of the evaluation of innovativeness, the following question was selected, "My company has a reputation of an innovator". In order to measure risk taking dimension, the question was chosen that "I'm not afraid to invest money in risky projects". With the purpose of assessing proactiveness, this query was picked that "We take initiative in our market to get ahead of a competition". Moreover, we have calculated to competitive aggressiveness by choosing the question that "We often do activities that are directed against competitors." Lastly, we have gauged the autonomy which consists of the query that "My company has a reputation of an autonomous company" (the owners of company act independently).

In this research, five scientific hypotheses were set for estimation. 
H1: There are statistically significant differences exists between the genders and the education levels of entrepreneurs and the age of firms in relation to innovativeness.

H2: There are statistically significant differences exists between the genders and the education levels of entrepreneurs and the age of firms in relation to risk taking.

H3: There are statistically significant differences exists between the genders and the education levels of entrepreneurs and the age of firms in relation to proactiveness.

H4: There are statistically significant differences exists between the genders and the education levels of entrepreneurs and the age of firms in relation to competitive aggressiveness.

H5: There are statistically significant differences exists between the genders and the education levels of entrepreneurs and the age of firms in relation to autonomy.

Pearson' chi square statistics were used at significance level of 5\% to analyse the sample and to show the statistically significant differences and dependences between selected factors. When $\mathrm{p}$ value is lower than the significance level of $5 \%$, the null hypothesis was rejected and alternative hypothesis was accepted. The null hypothesis assumes that there is not any statistically significant relationship between the selected factors. MS Excel and free statistical software were used to make calculations. The statistical software is available at http://www.socscistatistics.com/tests. Statistically significant differences in the individual responses were analysed by way of $\mathrm{Z}$ score. The free software was applied to perform calculations and the software is in existence at: http://www.socscistatistics.com/tests/ztest/Default2.aspx.

\section{RESULTS AND DISCUSSION}

Table 1 indicates the results of our research in connection with the measurement of innovativeness among men and women, different education levels of entrepreneurs and age of the firms.

Table 1. Evaluation of innovativeness among gender and education level of micro entrepreneurs and micro enterprises' age

\begin{tabular}{|c|c|c|c|c|c|c|c|c|}
\hline $\begin{array}{l}\text { My company } \\
\text { has a reputation } \\
\text { of an innovator. } \\
\text { (innovativeness) }\end{array}$ & Total & Men & Women & $\begin{array}{l}\text { Secondary } \\
\text { education }\end{array}$ & $\begin{array}{c}\text { Other } \\
\text { types of } \\
\text { education }\end{array}$ & $\begin{array}{c}\text { Older } \\
\text { than } \\
10 \\
\text { years } \\
(10+)\end{array}$ & $\begin{array}{l}\text { Younger } \\
\text { than } 10 \\
\text { years } \\
(10-)\end{array}$ & $\begin{array}{c}\text { P-value } \\
\text { Z-score } \\
\text { M/W } \\
\mathrm{HE} / \mathrm{OE} \\
10+/ 10-\end{array}$ \\
\hline $\begin{array}{l}\text { Completely } \\
\text { agree and agree }\end{array}$ & $\begin{array}{c}269 \\
(36.35)\end{array}$ & $\begin{array}{c}193 \\
(35.74)\end{array}$ & $\begin{array}{c}76 \\
(38.00)\end{array}$ & $\begin{array}{c}92 \\
\mathbf{( 4 2 . 7 9 )}\end{array}$ & $\begin{array}{c}177 \\
(\mathbf{3 3 . 7 1})\end{array}$ & $\begin{array}{c}126 \\
\mathbf{( 3 2 . 3 1 )}\end{array}$ & $\begin{array}{c}143 \\
\mathbf{( 4 0 . 8 6 )}\end{array}$ & $\begin{array}{c}0.5619 \\
\mathbf{0 . 0 1 9 8} \\
\mathbf{0 . 0 1 6}\end{array}$ \\
\hline $\begin{array}{l}\text { I don't have a } \\
\text { position }\end{array}$ & $\begin{array}{c}299 \\
(40.41)\end{array}$ & $\begin{array}{c}225 \\
(41.67)\end{array}$ & $\begin{array}{c}74 \\
(37.00)\end{array}$ & $71(33.02)$ & $\begin{array}{c}228 \\
(43.43)\end{array}$ & $\begin{array}{c}174 \\
(44.62)\end{array}$ & $\begin{array}{c}125 \\
(35.71)\end{array}$ & $\begin{array}{l}0.2501 \\
0.0088 \\
0.9124 \\
\end{array}$ \\
\hline $\begin{array}{l}\text { Completely } \\
\text { disagree and } \\
\text { disagree }\end{array}$ & $\begin{array}{c}172 \\
(23.24)\end{array}$ & $\begin{array}{c}122 \\
(22.59)\end{array}$ & $\begin{array}{c}50 \\
(25.00)\end{array}$ & $\begin{array}{c}52 \\
(24.19)\end{array}$ & $\begin{array}{c}120 \\
(22.86)\end{array}$ & $\begin{array}{c}90 \\
(23.08)\end{array}$ & $\begin{array}{c}82 \\
(23.43)\end{array}$ & $\begin{array}{l}0.4902 \\
0.6965 \\
0.0139 \\
\end{array}$ \\
\hline Total: & 740 & 540 & 200 & 215 & 525 & 390 & 350 & \\
\hline $\begin{array}{l}\text { Chí - square/ } \\
\text { P-value }\end{array}$ & & $\begin{array}{l}1.7198 \\
0.7871 \\
\end{array}$ & & $\begin{array}{c}10.2691 \\
0.0361\end{array}$ & & $\begin{array}{l}\mathbf{8 . 2 4 7 5} \\
\mathbf{0 . 0 8 2 9} \\
\end{array}$ & & \\
\hline
\end{tabular}

Source: Own source

According to Table 1, our results for P value from Chi Square demonstrate that there are significant differences exists between the education levels of entrepreneurs and age of firms in the context of innovativeness. With regards to education levels, the P-value from Chi Square shows that our result is significant at 5\% significance level $(\mathrm{p}<0.05)$. We find that 92 (about 43\%) among 215 secondary 
educated micro entrepreneurs completely agree and agree that "My company has a reputation of an innovator". On the other hand, around 34\% lower educated people completely agree and agree with this fact. Also, $\mathrm{P}$ value from $\mathrm{Z}$ score is significant at $5 \%$ significance level $(\mathrm{p}<0.05)$ and shows that entrepreneurs who have graduated with university education are more innovative comparing with less educated micro entrepreneurs.

Considering the firm age, the $\mathrm{P}$ value from Chi Square is also significant but in $10 \%$ significance level $(0.0829<0.10)$. This result suggests that significant differences are in existence between older and younger micro firms. We obtain another result that 143 (about 41\%) owners of younger firms in total 350 micro entrepreneurs completely agree or agree with the following fact that "My company has a reputation of an innovator". On the other side, $\mathrm{P}$ value from $\mathrm{Z}$ score is significant at $5 \%$ level $(p<0.05)$ and indicates that younger micro enterprises are more innovative rather than older micro firms.

However, no statistical differences were found in innovativeness within the scope of gender of the micro entrepreneurs. $\mathrm{P}$ value from Chi Square is not significant in both significance levels $5 \%$ and $10 \%$.

The above mentioned results from Table 1, give an explanation to us that, we can partially accept our hypothesis 1 , due to rejecting the fact that men are more innovative than women. Our other assumptions are accepted because we find that university educated micro entrepreneurs and younger micro firms perform better than less educated micro entrepreneurs and older companies.

Table 2 shows the results of our research in relation with the measurement of risk taking among males and females, varied education levels of entrepreneurs and age of firms.

Table 2. Evaluation of risk taking amongst gender, education levels of micro entrepreneurs and micro enterprises' age

\begin{tabular}{|c|c|c|c|c|c|c|c|c|}
\hline $\begin{array}{l}\text { I'm not } \\
\text { afraid to } \\
\text { invest } \\
\text { money in } \\
\text { risky } \\
\text { projects. } \\
\text { (risk taking) }\end{array}$ & Total & Men & Women & $\begin{array}{l}\text { Secondary } \\
\text { education }\end{array}$ & $\begin{array}{c}\text { Other } \\
\text { types of } \\
\text { education }\end{array}$ & $\begin{array}{l}\text { Older } \\
\text { than } 10 \\
\text { years } \\
(10+)\end{array}$ & $\begin{array}{l}\text { Younger } \\
\text { than } 10 \\
\text { years } \\
(10-)\end{array}$ & $\begin{array}{c}\mathrm{P}- \\
\text { value } \\
\text { Z-score } \\
\mathrm{M} / \mathrm{W} \\
\mathrm{HE} / \mathrm{OE} \\
10+/ 10-\end{array}$ \\
\hline $\begin{array}{l}\text { Completely } \\
\text { agree and } \\
\text { agree }\end{array}$ & $\begin{array}{c}230 \\
(31.08)\end{array}$ & $\begin{array}{c}171 \\
(31.67)\end{array}$ & $\begin{array}{c}59 \\
(29.50)\end{array}$ & $\begin{array}{c}65 \\
(30.23)\end{array}$ & $\begin{array}{c}165 \\
(31.43)\end{array}$ & $\begin{array}{c}99 \\
\mathbf{( 2 5 . 3 8 )}\end{array}$ & $\begin{array}{c}131 \\
\mathbf{( 3 7 . 4 3 )}\end{array}$ & $\begin{array}{c}0.5754 \\
0.749 \\
\mathbf{0 . 0 0 0 4} \\
\end{array}$ \\
\hline $\begin{array}{l}\text { I don't have } \\
\text { a position }\end{array}$ & $\begin{array}{c}138 \\
(18.65)\end{array}$ & $\begin{array}{c}105 \\
(19.44)\end{array}$ & $\begin{array}{c}33 \\
(16.50)\end{array}$ & $32(14.88)$ & $\begin{array}{c}106 \\
(20.19)\end{array}$ & $\begin{array}{c}76 \\
(19.49)\end{array}$ & $\begin{array}{c}62 \\
(17.71)\end{array}$ & $\begin{array}{c}0.3628 \\
0.093 \\
0.5353 \\
\end{array}$ \\
\hline $\begin{array}{l}\text { Completely } \\
\text { disagree and } \\
\text { disagree }\end{array}$ & $\begin{array}{c}372 \\
(50.27)\end{array}$ & $\begin{array}{c}264 \\
(48.89)\end{array}$ & $\begin{array}{c}108 \\
(54.00)\end{array}$ & $\begin{array}{c}118 \\
(54.88)\end{array}$ & $\begin{array}{c}254 \\
(48.38)\end{array}$ & $\begin{array}{c}215 \\
\mathbf{( 5 5 . 1 3 )}\end{array}$ & $\begin{array}{c}157 \\
\mathbf{( 4 4 . 8 6 )}\end{array}$ & $\begin{array}{l}0.2076 \\
0.1074 \\
\mathbf{0 . 0 0 5 3} \\
\end{array}$ \\
\hline Total: & 740 & 540 & 200 & 215 & 525 & 390 & 350 & \\
\hline $\begin{array}{l}\text { chí - square/ } \\
\text { p-value }\end{array}$ & & $\begin{array}{l}2.7062 \\
0.6081 \\
\end{array}$ & & $\begin{array}{l}5.2973 \\
0.2581 \\
\end{array}$ & & $\begin{array}{c}13.8989 \\
0.0076 \\
\end{array}$ & & \\
\hline
\end{tabular}

Source: Own source.

With reference to Table 2, we observe that there are significant differences exist among younger and older micro enterprises in risk taking as $\mathrm{P}$ value from Chi Square is significant at 5\% significance level $(\mathrm{p}<0.05)$. When we consider $\mathrm{P}$ value from $\mathrm{Z}$ score, the result is also significant at 
$5 \%$ significance level. The result provides us to make a suggestion that younger micro enterprises are more risk taker than the older micro enterprises. 131 (about 37\%) owners of young micro enterprises in between 350 micro entrepreneurs are completely agree or agree the fact that "I'm not afraid to invest money in risky projects". But, only 99 (about 25\%) owners of old micro enterprises in between 390 micro entrepreneurs are completely agree or agree with this fact. On top of that, when we pay attention to $\mathrm{P}$ value from $\mathrm{Z}$ score for the section of disagree and completely disagree, $P$ value is significant and it means that comparing with younger firms' owners, higher percentage of owners of older micro entrepreneurs confirm that they are completely disagree and disagree with the fact that they are not afraid to invest their money to risky projects. Hence, we can conclude that they behave more risk averse than the owner of younger micro firms.

On the other hand, we do not find any significant differences between gender and education level of micro entrepreneurs with regards to risk taking. Statistically, $\mathrm{P}$ values from Chi Square and $\mathrm{Z}$ score are both insignificant. Because of having these results, again we can partially confirm our hypothesis 2. Although we accept one of our assumptions that younger firms take more risks than older firms, we reject both of those assumptions that men and more educated micro entrepreneurs are more risk taker than women and lower educated entrepreneurs.

Table 3 presents the results of our research with respect to the assessment of proactiveness among males and females, varied education levels of entrepreneurs and age of firms.

Table 3. Evaluation of proactiveness amongst gender, education levels of micro entrepreneurs and micro enterprises' age

\begin{tabular}{|c|c|c|c|c|c|c|c|c|}
\hline $\begin{array}{l}\text { We take } \\
\text { initiative in } \\
\text { our market to } \\
\text { get ahead of a } \\
\text { competition } \\
\text { (proactiveness) }\end{array}$ & Total & Men & Women & $\begin{array}{l}\text { Secondary } \\
\text { education }\end{array}$ & $\begin{array}{c}\text { Other } \\
\text { types of } \\
\text { education }\end{array}$ & $\begin{array}{l}\text { Older } \\
\text { than } 10 \\
\text { years } \\
(10+)\end{array}$ & $\begin{array}{c}\text { Younger } \\
\text { than } 10 \\
\text { years } \\
(10-)\end{array}$ & $\begin{array}{c}\mathrm{P}- \\
\text { value } \\
\mathrm{Z} \text {-score } \\
\mathrm{M} / \mathrm{W} \\
\mathrm{HE} / \mathrm{OE} \\
10+/ 10-\end{array}$ \\
\hline $\begin{array}{l}\text { Completely } \\
\text { agree and } \\
\text { agree }\end{array}$ & $\begin{array}{c}427 \\
(57.70)\end{array}$ & $\begin{array}{c}305 \\
(56.48)\end{array}$ & $\begin{array}{c}122 \\
(61.00)\end{array}$ & $\begin{array}{c}120 \\
(55.81)\end{array}$ & $\begin{array}{c}307 \\
(58.48)\end{array}$ & $\begin{array}{c}207 \\
\mathbf{( 5 3 . 0 8 )}\end{array}$ & $\begin{array}{c}220 \\
(\mathbf{6 2 . 8 6})\end{array}$ & $\begin{array}{l}0.2627 \\
0.5029 \\
\mathbf{0 . 0 0 7 1}\end{array}$ \\
\hline $\begin{array}{l}\text { I don't have a } \\
\text { position }\end{array}$ & $\begin{array}{c}188 \\
(25.41)\end{array}$ & $\begin{array}{c}137 \\
(25.37)\end{array}$ & $\begin{array}{c}51 \\
(25.50)\end{array}$ & $\begin{array}{c}60 \\
(27.91)\end{array}$ & $\begin{array}{c}128 \\
(24.38)\end{array}$ & $\begin{array}{c}115 \\
(29.49)\end{array}$ & $\begin{array}{c}73 \\
(20.86)\end{array}$ & $\begin{array}{l}0.9681 \\
0.3173 \\
0.0071\end{array}$ \\
\hline $\begin{array}{l}\text { Completely } \\
\text { disagree and } \\
\text { disagree }\end{array}$ & $\begin{array}{c}125 \\
(16.89)\end{array}$ & $\begin{array}{c}98 \\
(18.15)\end{array}$ & $\begin{array}{c}27 \\
(13.50)\end{array}$ & $\begin{array}{c}35 \\
(16.28)\end{array}$ & $\begin{array}{c}90 \\
(17.14)\end{array}$ & $\begin{array}{c}68 \\
(17.44)\end{array}$ & $\begin{array}{c}57 \\
(16.29)\end{array}$ & $\begin{array}{l}0.0264 \\
0.7795 \\
0.6745\end{array}$ \\
\hline Total: & 740 & 540 & 200 & 215 & 525 & 390 & 350 & \\
\hline $\begin{array}{l}\text { chí - square/ } \\
\text { p-value }\end{array}$ & & $\begin{array}{l}4.8953 \\
0.2982\end{array}$ & & $\begin{array}{l}2.4129 \\
0.6603 \\
\end{array}$ & & $\begin{array}{c}10.3309 \\
0.0352\end{array}$ & & \\
\hline
\end{tabular}

Source: Own source.

We find similar results with the dimension of risk taking, when we analyse the proactiveness. Our results suggest that there are significant differences exists between younger and older micro enterprises in respect to proactiveness. When we look at the P value from Chi-Square in the table 3 for the section of age of the firms, the $P$ value is statistically significant at $5 \%$ significance level $(p<0.05)$. Furthermore, the $p$ value from $Z$ score $(0.0071)$ is also significant at $5 \%$ significance level and it proves that younger micro firms are more proactive than older micro firms. 220 (about 63\%) respondents from younger micro firms in between 350 younger micro firms completely agree or agree that "We take initiative in our market to get ahead of a competition". On the other hand, 207 
(around 53\%) respondents from older micro firms in between 390 older micro firms completely agree or agree with this opinion.

However, we do not receive any significant differences between gender and education level of owners of micro firms. $\mathrm{P}$ values from Chi Square and $\mathrm{Z}$ score are not significant for the variables of gender and education level with regard to proactiveness.

In consideration of these results, we can again partially accept our hypothesis 3 . We can only prove that younger firms are better in the dimension of proactiveness than older firms. On the other hand, we do not find any significant differences between not only for women and men, but also higher educated and lower educated entrepreneurs in the context of proactiveness.

Table 4 reveals the results of our research in the context of the appraisement of competitive aggressiveness in between men and women, various education levels of micro entrepreneurs and micro enterprises' age.

Table 4. Evaluation of competitive aggressiveness amongst gender, education levels of micro entrepreneurs and micro enterprises' age

\begin{tabular}{|c|c|c|c|c|c|c|c|c|}
\hline $\begin{array}{l}\text { We often do } \\
\text { activities that } \\
\text { are directed } \\
\text { against } \\
\text { competitors. } \\
\text { (competitive } \\
\text { aggressiveness) }\end{array}$ & Total & Men & Women & $\begin{array}{l}\text { Secondary } \\
\text { education }\end{array}$ & $\begin{array}{c}\text { Other } \\
\text { types of } \\
\text { education }\end{array}$ & $\begin{array}{c}\text { Older } \\
\text { than } \\
10 \\
\text { years } \\
(10+)\end{array}$ & $\begin{array}{c}\text { Younger } \\
\text { than } 10 \\
\text { years } \\
(10-)\end{array}$ & $\begin{array}{c}\text { P- } \\
\text { value } \\
\text { Z-score } \\
\mathrm{M} / \mathrm{W} \\
\mathrm{HE} / \mathrm{OE} \\
10+/ 10-\end{array}$ \\
\hline $\begin{array}{l}\text { Completely } \\
\text { agree and agree }\end{array}$ & $\begin{array}{c}157 \\
(21.22)\end{array}$ & $\begin{array}{c}111 \\
(20.56)\end{array}$ & $\begin{array}{c}46 \\
(23.00)\end{array}$ & $\begin{array}{c}41 \\
(19.07)\end{array}$ & $\begin{array}{c}116 \\
(22.10)\end{array}$ & $\begin{array}{c}79 \\
(20.26)\end{array}$ & $\begin{array}{c}78 \\
(22.29)\end{array}$ & $\begin{array}{l}0.4715 \\
0.3628 \\
0.5029\end{array}$ \\
\hline $\begin{array}{l}\text { I don't have a } \\
\text { position }\end{array}$ & $\begin{array}{c}162 \\
(21.89)\end{array}$ & $\begin{array}{c}116 \\
(21.48)\end{array}$ & $\begin{array}{c}46 \\
(23.00)\end{array}$ & $\begin{array}{c}41 \\
(19.07)\end{array}$ & $\begin{array}{c}121 \\
(23.05)\end{array}$ & $\begin{array}{c}87 \\
(22.31)\end{array}$ & $\begin{array}{c}75 \\
(21.43)\end{array}$ & $\begin{array}{l}0.6599 \\
0.2340 \\
0.7718\end{array}$ \\
\hline $\begin{array}{l}\text { Completely } \\
\text { disagree and } \\
\text { disagree }\end{array}$ & $\begin{array}{c}421 \\
(56.89)\end{array}$ & $\begin{array}{c}313 \\
(57.96)\end{array}$ & $\begin{array}{c}108 \\
(54.00)\end{array}$ & $\begin{array}{c}133 \\
\mathbf{( 6 1 . 8 6 )}\end{array}$ & $\begin{array}{c}288 \\
(\mathbf{5 4 . 8 6 )}\end{array}$ & $\begin{array}{c}224 \\
(57.44)\end{array}$ & $\begin{array}{c}197 \\
(56.29)\end{array}$ & $\begin{array}{c}0.3320 \\
\mathbf{0 . 0 8 0 1} \\
0.749\end{array}$ \\
\hline Total: & 740 & 540 & 200 & 215 & 525 & 390 & 350 & \\
\hline $\begin{array}{l}\text { chí - square/ } \\
\text { p-value }\end{array}$ & & $\begin{array}{l}1.2569 \\
0.8687 \\
\end{array}$ & & $\begin{array}{c}10.7808 \\
0.0291 \\
\end{array}$ & & $\begin{array}{l}1.7307 \\
0.7851 \\
\end{array}$ & & \\
\hline
\end{tabular}

Source: Own source.

When we consider the education level of micro entrepreneurs, $\mathrm{P}$ value from Chi Square indicates that there are significant differences exist between the university educated and lower educated entrepreneurs according to competitive aggressiveness $(\mathrm{p}<0.05)$. We can also notice from our calculation that $\mathrm{P}$ value from $\mathrm{Z}$ score for disagreed and completely disagreed respondents in the context of level of education is statistically significant at $10 \%$ significance level. This result shows that comparing with lower educated micro entrepreneurs, higher percentage of micro entrepreneurs who have university degree completely disagree and disagree with the opinion that "We often do activities that are directed against competitors". Although, we find that they are more against to the opinion that is based on competitive aggressiveness, statistically we do not get any significant result that lower educated micro entrepreneurs are more competitive than others.

On the other hand, the results also indicate that there is no significant difference between the older and younger micro enterprises and also men and women micro entrepreneurs in relation with 
competitive aggressiveness. Our both $\mathrm{P}$ values from $\mathrm{Z}$ score and Chi Square are not significant to explain the differences between them.

When examining all of these results with regards to competitive aggressiveness, we reject our hypothesis 4 . We do not have any significant findings to accept our hypothesis that males, university educated entrepreneurs and younger firms are better in the dimension of competitive aggressiveness than females, lower educated entrepreneurs and older firms.

The results of our research in the context of the assessment of autonomy among men and women, various education levels of entrepreneurs and older and younger firms were presented in the Table 5.

Table 5: Evaluation of autonomy amongst genders, education levels of micro entrepreneurs and micro enterprises' age

\begin{tabular}{|c|c|c|c|c|c|c|c|c|}
\hline $\begin{array}{l}\text { My company } \\
\text { has a } \\
\text { reputation of } \\
\text { an autonomous } \\
\text { company (the } \\
\text { owners of } \\
\text { company act } \\
\text { independently). } \\
\text { (Autonomy) }\end{array}$ & Total & Men & Women & $\begin{array}{l}\text { Secondary } \\
\text { education }\end{array}$ & $\begin{array}{c}\text { Other } \\
\text { types of } \\
\text { education }\end{array}$ & $\begin{array}{c}\text { Older } \\
\text { than } \\
10 \\
\text { years } \\
(10+)\end{array}$ & $\begin{array}{c}\text { Younger } \\
\text { than } 10 \\
\text { years } \\
(10-)\end{array}$ & $\begin{array}{c}\mathrm{P}- \\
\text { value } \\
\mathrm{Z} \text {-score } \\
\mathrm{M} / \mathrm{W} \\
\mathrm{HE} / \mathrm{OE} \\
10+/ 10-\end{array}$ \\
\hline $\begin{array}{l}\text { Completely } \\
\text { agree and agree }\end{array}$ & $\begin{array}{c}358 \\
(48.38)\end{array}$ & $\begin{array}{c}256 \\
(47.41)\end{array}$ & $\begin{array}{c}102 \\
(51.00)\end{array}$ & $\begin{array}{c}124 \\
\mathbf{( 5 7 . 6 7 )}\end{array}$ & $\begin{array}{c}234 \\
(\mathbf{4 4 . 5 7 )}\end{array}$ & $\begin{array}{c}188 \\
(48.21)\end{array}$ & $\begin{array}{c}170 \\
(48.57)\end{array}$ & $\begin{array}{l}0.3843 \\
\mathbf{0 . 0 0 1 2} \\
0.9203\end{array}$ \\
\hline $\begin{array}{l}\text { I don't have a } \\
\text { position }\end{array}$ & $\begin{array}{c}172 \\
(23.24)\end{array}$ & $\begin{array}{c}122 \\
(22.59)\end{array}$ & $\begin{array}{c}50 \\
(25.00)\end{array}$ & $\begin{array}{c}52 \\
(24.19)\end{array}$ & $\begin{array}{c}120 \\
(22.86)\end{array}$ & $\begin{array}{c}83 \\
(21.28)\end{array}$ & $\begin{array}{c}89 \\
(25.43)\end{array}$ & $\begin{array}{l}0.4902 \\
0.6965 \\
0.1835\end{array}$ \\
\hline $\begin{array}{l}\text { Completely } \\
\text { disagree and } \\
\text { disagree } \\
\end{array}$ & $\begin{array}{c}210 \\
(28.38)\end{array}$ & $\begin{array}{c}162 \\
(30.00)\end{array}$ & $\begin{array}{c}48 \\
(24.00)\end{array}$ & $\begin{array}{c}39 \\
\mathbf{( 1 8 . 1 4 )}\end{array}$ & $\begin{array}{c}171 \\
(\mathbf{3 2 . 5 7})\end{array}$ & $\begin{array}{c}119 \\
(30.51)\end{array}$ & $\begin{array}{c}91 \\
(26.00)\end{array}$ & $\begin{array}{c}0.1074 \\
\text { 8E-05 } \\
0.1738 \\
\end{array}$ \\
\hline Total: & 740 & 540 & 200 & 215 & 525 & 390 & 350 & \\
\hline $\begin{array}{l}\text { chí - square/ } \\
\text { p-value }\end{array}$ & & $\begin{array}{l}4.1301 \\
0.3887 \\
\end{array}$ & & $\begin{array}{c}18.4964 \\
0.0009 \\
\end{array}$ & & $\begin{array}{c}2.7128 \\
0.607\end{array}$ & & \\
\hline
\end{tabular}

Source: Own source.

The most important result for this table is that significant differences are exists between education levels of micro entrepreneurs with respect to autonomy due to having significant $\mathrm{P}$ value from Chi Square at 5\% level. 124 (around 58\%) university educated owners of micro enterprises in between 215 owners of micro enterprises completely agree or agree with the fact that "My company has a reputation of an autonomous company". By contrast with this finding, 234 respondents (around $45 \%$ ) who have lower education level, completely agree and agree with the opinion. On top of that, $\mathrm{P}$ value from $\mathrm{Z}$ score is also significant at 5\% significance level and it is almost level of certainty. Owing to this result, we can support one of our proposals that higher educated entrepreneurs are more autonomous comparing with their lower educated counterparts. Additionally, we can also provide a finding that the difference of lower and highly educated entrepreneurs who are completely disagreed and disagreed is also significant that shows lower educated micro entrepreneurs are more disagree the opinion that their firm has a reputation of an autonomous firm.

On the other hand, $\mathrm{P}$ value from $\mathrm{Z}$ score and Chi Square are not statistically significant at 5\% level for the genders and age of firms in the context of autonomy. For this reason, our results indicate that 
there is no significant difference between men and women micro entrepreneurs and older and younger micro firms in relation to autonomy. Consequently, we can only partially confirm our hypothesis 5. Only one of our assumptions about autonomy is supported that high educated entrepreneurs have more autonomy than their lower educated counterparts. Our other assumptions for autonomy such as males are more autonomous than women and younger firms behave more autonomously than older firms are rejected.

Some results of our study indicate that there is no statistical difference exists in relation with the all dimensions of EO such as, innovativeness, risk taking, proactiveness, competitive aggressiveness, autonomy in between men and women in the segment of micro enterprises. Our results show some similarities with the study of Jelenc et al. (2015) also does not find any differences with regard to dimensions of risk taking and innovativeness. Considering the research of Runyan et al. (2006), one of our results also same with their finding that no difference is in existence in relation to proactiveness among genders. In terms of the dimension of autonomy, another important result of our research is also very similar with the work of Bird (1993) that finds females and males have strong similarities in autonomy. With respect to the competitive aggressiveness, our result is opposed to the research of Lim and Envick (2011). Although we get a result that there is not any significant difference in competitive aggressiveness between females and males, Lim and Envick (2011) prove that males are more aggressive in the competitiveness comparing with females.

As we mentioned above that, no significant differences are found between men and women in relation with all components of EO which are examined in this study. This important result can be related with education levels which the respondents have in our sample. Cowling and Taylor (2001), highlight that there are some proof in some developed countries that women entrepreneurs participate higher education levels more than men and their overall level of education is significantly higher comparing with their men counterparts. According to our data which consists of Czech micro entrepreneurs, $37 \%$ of women micro entrepreneurs have university degree whereas only $25 \%$ of men micro entrepreneurs are graduated from university. This finding proves the expression of Cowling and Taylor (2001). Furthermore, Carter et al. (2007) provide an explanation that the gender criteria for loan process diminish when higher level of education is taken into consideration. Similarly, Wilson et al. (2007), emphasize that when men and women entrepreneurs access to market, higher education can mitigate the differences between them. By investigating 235 women entrepreneurs in USA, Carter et al. (2003) find that higher educated women entrepreneurs are more prone to get funded by external financing comparing with less educated women. All these studies provide us to make a suggestion that because of being high educated and using the opportunities of market, women micro entrepreneurs in our sample could behave as same as their male counterparts in the dimensions of EO. It can be also a reason for us to have no significant differences in our assessments.

When we consider the education level of micro entrepreneurs, our results show significant differences with regard to innovativeness, competitive aggressiveness and autonomy. However, there is no statistically significant difference exists between various levels of education in relation with competitive aggressiveness so we reject one of our assumptions that higher educated entrepreneurs act more in the competitive aggressiveness than their lower educated counterparts. On the other hand, our results also demonstrate that higher educated micro entrepreneurs perform better in innovativeness and autonomy comparing with their less educated counterparts. In this respect, we get similar findings with Altinay and Wang (2011) that prove education is positively related with innovativeness. But, our results do not show the positive relationship between education and the both dimensions of EO, risk taking and proactiveness which is not same as the study of Altinay and Wang (2011) that finds the positive relationship among these variables. 
Moreover, one of our results which is related to autonomy shows some similarities with the research of Ismail (2014). Ismail (2014) finds the differences between the level of education and need for autonomy among Indonesian women entrepreneurs. Although, our results prove that micro entrepreneurs who have university degree are more innovative and autonomous than lower educated micro entrepreneurs, we do not get any result that there are differences exist in between highly educated and lower educated micro entrepreneurs in terms of risk taking and proactiveness. So our results can make some suggestions that highly educated entrepreneurs in our sample could have more knowledge about the process of their business and could have more different competencies in their decision making process so they could be more innovative and autonomous comparing with their lower educated counterparts. Presumably, because of the uncertainty in the Czech market, more educated micro entrepreneurs can act same as their less educated counterparts with regard to risk taking and proactiveness and therefore, our results do not show the differences between education levels.

According to our results in terms of age of firms, we observe that significant differences are exists in regard to innovativeness, risk taking and competitive aggressiveness in between older and younger micro firms. We also receive statistically significant results that younger firms are better than the older firms in three dimensions of EO, such as innovativeness, risk taking and proactiveness. These results demonstrate similarities with the studies of Anderson and Eshima (2013) and Rosenbusch et al. (2011) that also present younger firms perform more actively than older firms in innovativeness, risk taking and proactiveness. Because of their more flexible structure and lower level of processes comparing with older firms, younger firms can make radical decisions to change their operations, production processes or business lines easier than older firms. In this regard, our results suggest that younger firms are more innovative, risk taker and proactive than older firms.

However, our results do not provide any significant differences among older and younger micro enterprises in the context of autonomy and competitive aggressiveness. As we already explained elsewhere, because of being more experienced, older firms can have some opportunities such as having more observation and being aware of market conditions. Having these abilities can give older firms a chance to close the gap between younger firms so as our results suggest they behave as same as younger firms with regard to both dimensions of EO, competitive aggressiveness and autonomy.

\section{CONCLUSION}

The objective of the study was to explore the differences in gender and education level of entrepreneurs and enterprises' age in connection with their EO in the segment of micro enterprises. Our data that is created by a survey of the quality of the business environment consists of randomly selected 1650 SMEs in the Albertina database. But our sample includes 1141 of SMEs and 740 of them are identified as micro enterprises. The survey was fulfilled in 2015 in fourteen different regions of Czech Republic. Due to having lack of studies which include all five dimensions of EO, we have analysed all these dimensions namely, innovativeness, risk taking, proactiveness, competitive aggressiveness and autonomy.

The results of our study suggests that university educated micro entrepreneurs are more innovative and autonomous than their lower educated counterparts. Moreover, the results of our research suggest that younger micro enterprises are more innovative, risk taker and proactive than older micro enterprises. However, our results do not find any significant differences between women and men micro entrepreneurs in relation with all dimensions of EO which we have examined in this study. Furthermore, some of our results show no differences between education levels of micro 
entrepreneurs in the context of risk taking and proactiveness and also amongst older and younger micro enterprises with respect to their competitive aggressiveness and autonomy.

Although we include all dimensions of EO and different characteristics of entrepreneurs and enterprises in our comprehensive research, our study has some boundaries and limitations. For instance, we have limited data that only contains a country namely, Czech Republic. Because of this limitation, we cannot look from a broader perspective and we cannot be aware of the dissimilarities and similarities among different countries. Furthermore, in respect to segments of firms, our only focus is micro enterprises. Another important limitation is that, we have not considered some of demographic characteristics of entrepreneurs and enterprises, such as age of entrepreneurs and location of enterprises and so on. For these reasons, these limitations can give significant opportunities for future research.

\section{ACKNOWLEDGEMENTS}

The authors are thankful to the Internal Grant Agency of FaME TBU No. IGA/FaME/2015/025: The possibilities of the financial performance growth for commercial banks in the context of the credit risk of SME and the customer satisfaction, for financial support to carry out this research.

\section{REFERENCES}

1. Altinay, L., Wang, C. L. (2011), The influence of an entrepreneur's socio-cultural characteristics on the entrepreneurial orientation of small firms, Journal of Small Business and Enterprise Development, Vol. 18, No. 4, pp. 673-694.

2. Anderson, B. S., Eshima, Y. (2013), The influence of firm age and intangible resources on the relationship between entrepreneurial orientation and firm growth among Japanese SMEs, Journal of Business Venturing, Vol. 28, pp. 413-429.

3. Arenius, P., Minniti, M., (2005), Perceptual Variables and Nascent Entrepreneurs, Small Business Economics, Vol. 24, pp. 233-247.

4. Ayub, A., Razzaq, A., Aslam, M. S., Iftekhar, H. (2013), Gender effects on Entrenreneurial orientation and value innovation: evidence from Pakistan, European Journal of Business and Social Sciences, Vol. 2(1), pp. 82-90.

5. Bartoš, P., Rahman, A., Horák, J., Jáčová, H. (2015), Education and entrepreneurship in the SME segment in economic transformation, Economics and Sociology, Vol. 8, No 2, 2015, pp. 227239.

6. Belás, J., Vojtovič, S., Ključnikov, A. (2016), Microenterprises and Significant Risk Factors in Loan Process, Economics and Sociology, Vol. 9, No 1, pp. 43-59.

7. Berrone, P., Gertel, H., Giuliodori, R., Bernard, L., Meiners, E. (2014), Determinants of Performance in Microenterprises: Preliminary Evidence from Argentina, Journal of Small Business Management, 52(3), pp. 477-500.

8. Bird, B. J. (1993), Demographic approaches to entrepreneurship: The role of experience and background, Advances in Entrepreneurship, Firm Emergence and Growth, 1, pp. $11-48$.

9. Brugger, E. and Rajapatirana, S. (1995), New perspectives on financing small business in developing countries, San Francisco, Institute for Contemporary Studies Press.

10. Brunow, S., Hirte, G. (2006), Age structure and regional economic growth, Review of Regional Research, Vol. 26, pp. 3-26.

11. Carter, N. M., Brush, C. G., Greene, P. G., Gatewood, E., Hart, M. M., (2003), Women entrepreneurs who break through to equity financing: the Influence of human capital, social and financial capital, Venture Capital, Vol. 5(1), pp. 1-28. 
12. Carter, S., Shaw, E., Lam, W., Wilson, F. (2007), Gender, entrepreneurship, and bank lending: The criteria and processes used by bank loan officers in assessing applications, Entrepreneurship Theory and Practice, Vol. 31(3), pp. 427-444.

13. Clercq, D. D., Arenius, P. (2006), The role of knowledge in business start-up activity, International Small Business Journal, Vol. 24 No. 4, pp. 339-58.

14. Covin, J. G., Lumpkin G. T. (2011), Entrepreneurial orientation theory and research: Reflections on a needed construct, Entrepreneurship Theory and Practice, pp. 855-872. DOI: 10.1111/j.1540-6520.2011.00482.x.

15. Covin, J. G., Wales, G. (2012), The measurement of entrepreneurial orientation, Entrepreneurship Theory and Practice, pp. 677-702. DOI: 10.1111/j.1540-6520.2010.00432.x.

16. Cowling, M., Taylor, M. (2001), Entrepreneurial women and men: Two different species? Small Business Economics, Vol. 16(3), 167-176.

17. Cressy, R. (1996), Are business startups debt-rationed? , Economic Journal 106, pp. 12531270.

18. De Winne, S., Sels, L. (2010), Interrelationships between human capital, HRM and innovation in Belgian start-Ups aiming at an innovation strategy, International Journal of Human Resource Management, Vol. 21, pp. 1863-1883.

19. Diaz-Garcia, M. C., Jimenez-Moreno, J. (2010), Entrepreneurial intention: the role of gender, International Entrepreneurship Management Journal, Vol. 6, pp. 261-283.

20. Eisenhardt, K.M. (1989), Making fast strategic decisions in high-velocity environments, Academy of Management Journal, Vol. 32, pp. 543-576.

21. Goktan, A. B., Gupta, V. K., (2015), Sex, gender, and individual entrepreneurial orientation: evidence from four countries, International Entrepreneurship and management Journal, Vol. 11, pp. 95-112.

22. Hausman, A. (2005), Innovativeness among small business: Theory and propositions for future research, Industrial Marketing Management, Vol. 34, pp. 773-782.

23. Islam, A. M., Khan, A. M., Obaidullah, M. Z. A. and Alam, N. S., (2011), "Effect of entrepreneur and firm characteristics on the business success of SMEs in Bangladesh", International Journal of Business and Management, Vol. 6(3), pp. 289-299.

24. Ismail, V. Y. (2014), The Comparison of Entrepreneurial Competency in Woman Micro-, Small-, and Medium-scale Entrepreneurs", Procedia - Social and Behavioral Sciences , Vol. 115, pp. 175-187.

25. Jelenc, L., Pisapia, J., Ivanusic, N. (2015), Demographic Variables Influencing Individual Entrepreneurial Orıentation and Strategic Thinking Capability, 10th International Scientific Conference on Economic and Social Development - Miami.

26. Ključnikov, A., Belás, J., Kozubíková L., Paseková P. (2016), The Entreprenurial Perception of SME Business Environment Quality in the Czech Republic, Journal of Competitiveness, Vol. 8, Issue 1, pp. $66-78$.

27. Kraus, S. (2013), The role of entrepreneurial orientation in service firms: emprical evidence from Austria, The Service Industries Journal, Vol. 33, No. 5, pp. 427 -444.

28. Kato, M., Okamuro, H., Honjo, Y. (2015), Does founder human capital matter for innovation? Evidence from Japanese start-ups, Journal of Small Business Management, Vol. 53(1), pp. 114-128.

29. Laforet, S. (2013), "Organizational innovative outcomes in SMEs: effects of size, age and sector", Journal of World Business, Vol. 48, pp. 490-502.

30. Langowitz, N., Minniti, M. (2007), Entrepreneurial propensity of women, Entrepreneurship Theory and Practice, Vol. 313, pp. 341-364.

31. Larson, D. W., Shaw, T. K. (2001), Issues of microenterprise and agricultural growth: do opportunities exist through forward and backward linkages? , Journal of Developmental Entrepreneurship, 6(3), pp. 203-220.

32. Lechner, C., Gudmundsson V. S. (2014), Entrepreneurial orientation, firm strategy and small firm performance, International Small Business Journal, Vol. 32(1), pp. 36-60. 
33. Levesque, M., Minniti, M. (2006), The effect of aging on entrepreneurial behavior", Journal of Business Venturing, Vol. 21, pp. 177- 194.

34. Levesque, M., Minniti, M., (2011), Age matters: How demographics influence aggregate entrepreneurship, Strategic Entrepreneurship Journal, Vol. 5, pp. 255-284.

35. Liedholm, C. (1990), The dynamics of small scale industry in Africa and the role of policy, Michigan State University, East Lansing, MI ( unpublished draft)

36. Lim, S., Envick, E. R., (2013), Gender and Entrepreneurial Orientation: A Multi Country Study, International Entrepreneurship and Management Journal, Vol. 9, pp. 465-482.

37. Lumpkin, G. T., Dess, G. G. (1996), Clarifying the entrepreneurial orientation construct and linking it to performance, Academy of Management Review 21(1), pp. 135-172.

38. Luo, X., Zhuo, L., Liu, S. (2005), Entrepreneurial firms in the context of China's transition economy: An integrative framework and empirical examination, Journal of Business Research, Vol. 58, pp. 277-284.

39. Mamman, A. (2014), Effect of entrepreneurship education on capacity building in Small and Medium Scale Enterprises (SMEs) in Nigeria, International Journal of Social Sciences and Entrepreneurship, Vol. 1(11), pp. 1-11.

40. Marques, C. S. E., Ferriera J .J. M., Ferriera, F. A. F., Lages, M. F. S. (2013), Entrepreneurial orientation and motivation to start-up a business: evidence from the health service industry, International Entrepreneurship Management Journal, Vol. 9, pp. 77-94.

41. Mengistae, T. (2006), Competition and entrepreneurs, human capital in small business longevity and growth, Journal of Development Studies, Vol. 42(5), pp. 812-836.

42. Mervel, M. R., Lumpkin G. T. (2007), Technology Entrepreneurs' human capital and Its effect on innovation radicalness, Enterprises Theory and Practice, pp. 807-828.

43. Miller, D. (1983), The correlates of entrepreneurship in three types of firms, Management Science, 29(7), pp. 770-791.

44. Minniti, M., Nardone, C. (2007), Being in someone else's shoes: The role of gender in nascent entrepreneurship, Small Business Economics, Vol: 28, pp. 223-238.

45. Mintzberg, H. (1973), Strategy-making in three modes, California Management Review, 16(2), pp. 44-53.

46. Moreno, A., Casillas, J. (2008), Entrepreneurial orientation and growths of SMEs: A causal model, Entrepreneurship Theory and Practice, 32(3), pp. 507-528.

47. Moss, T. V., Neubaum, D. O., Meyskens, M. (2015), The effect of virtuous and entrepreneurial orientations on microfinance lending and repayment: A signaling theory perspective, Entrepreneurship Theory and Practice, pp.27-52.

48. O'Gorman, C., Terjesen, S. (2006), Financing the Celtic Tigress: Venture financing and informal investment in Ireland, Venture Capital, Vol. 8(1), pp. 69-88.

49. Oosterbeek, H., Van Praag, M., Ijsselstein, A., (2010), The impact of entrepreneurship education on entrepreneurship skills and motivation, European Economic Review, Vol. 54, pp. 442454.

50. Pett, T. L., Wolff, J. A. (2012), SME Identity and Homogeneity- Are There Meaningful Differences Between, Micro, Small, and Medium-Sized Enterprises?, International Council for Small Business, pp. 15-18.

51. Powell, M., Ansic, D. (1997), Gender difference in risk behavior in financial decisionmaking: an experimental analysis, Journal of Economic Psychology, Vol. 18 No. 6, pp. 605-628.

52. Rauch, A., Rijsdijk, S. A. (2013), The effects of general and specific human capital on longterm growth and failure of newly founded businesses, Entrepreneurship Theory and Practice, Vol. 37(4), pp. 923-941.

53. Rosenbusch, N., Brinckmann, J., Bausch, A. (2011), Is innovation always beneficial? A meta-analysis of the relationship between innovation and performance in SMEs. Journal of Business Venturing, Vol. 26, 441-457. 
54. Roxas, B., Chadee, D. (2012), Effects of informal institutions on the performance of microenterprises in the Philippines: The mediating role of entrepreneurial orientation", Journal of Asia-Pacific Business, Vol. 13, pp. 320-348.

55. Runyan, R., Huddleston, P., Swinney, J. (2006), Entrepreneurial orientation and social capital as small firm strategies: A study of gender differences from a resource-based view, International Entrepreneurship and Management Journal, 2(4), pp. 455-477.

56. Sexton, D. L., Bowman-Upton, N. (1990), Female and male entrepreneurs: Psychological characteristics and their role in gender-related discrimination, Journal of Business Venturing, 5, 2936 .

57. Skokan K., Pawliczek A., Piszczur R. (2013), Strategic planning and business performance of Micro, Small and Medium-Sized Enterprises, Journal of Competitiveness, Vol. 5, Issue 4, pp. 5772.

58. Thapa, A. (2015), Determinants of microenterprise performance in Nepal, Small Business Economy, Vol. 45, pp. 581-594.

59. The Commission of the European Communities (2003), Commission recommendation, Official Journal of European Union, http://eur-lex.europa.eu/LexUriServ/LexUriServ. do? uri=OJ:L:2003:124:0036: 0041:EN:PDF. Accessed 11 May 2016.

60. Van der Sluis, Van Praag, M., Vijverberg, W. (2005), Entrepreneurship selection and performance: A meta-analysis of the impact of education in developing countries, The World Bank Economic Review, Vol. 13(2), pp. 225-261.

61. Wagner, J. (2007), What a difference a Y makes-female and male nascent entrepreneurs in Germany. Small Business Economics, 28(1), pp. 1-21. doi:10.1007/s11187-005-0259-x.

62. Welsh, D. H. B., Munoz, J. M., Deng, S., Raven, P. V. (2013), Microenterprise performance and microenterprise zones (MEZOs) in China, Management Decision, Vol. 51(1), pp. 25-40.

63. Wilson, F. Kickul, J., Marlino, D. (2007), Gender, entrepreneurial self-Efficacy, and entrepreneurial career intentions: implications for entrepreneurship education, Entrepreneurship Theory and Practice, Vol. 31(3), pp. 387-406. 